OPEN ACCESS

Edited by:

Hongyue Dang,

Xiamen University, China

Reviewed by:

Kai Ziervogel,

University of New Hampshire, USA Daniel Conrad Ogilvie Thornton,

Texas A\&M University, USA

*Correspondence:

Peter Stie

peterstief@biology.sdu.dk

Specialty section:

This article was submitted to

Aquatic Microbiology,

a section of the journal

Frontiers in Microbiology

Received: 01 December 2015

Accepted: 18 January 2016

Published: 05 February 2016

Citation:

Stief P, Kamp A, Thamdrup B and Glud RN (2016) Anaerobic Nitrogen Turnover by Sinking Diatom

Aggregates at Varying Ambient

Oxygen Levels. Front. Microbiol. 7:98.

doi: 10.3389/fmicb.2016.00098

\section{Anaerobic Nitrogen Turnover by Sinking Diatom Aggregates at Varying Ambient Oxygen Levels}

\author{
Peter Stief ${ }^{1 *}$, Anja Kamp ${ }^{2}$, Bo Thamdrup ${ }^{1}$ and Ronnie N. Glud ${ }^{1}$ \\ ${ }^{1}$ Department of Biology and Nordic Center for Earth Evolution, University of Southern Denmark, Odense, Denmark, ${ }^{2}$ AlAS, \\ Aarhus Institute of Advanced Studies, Aarhus University, Aarhus, Denmark
}

In the world's oceans, even relatively low oxygen levels inhibit anaerobic nitrogen cycling by free-living microbes. Sinking organic aggregates, however, might provide oxygen-depleted microbial hotspots in otherwise oxygenated surface waters. Here, we show that sinking diatom aggregates can host anaerobic nitrogen cycling at ambient oxygen levels well above the hypoxic threshold. Aggregates were produced from the ubiquitous diatom Skeletonema marinoi and the natural microbial community of seawater. Microsensor profiling through the center of sinking aggregates revealed internal anoxia at ambient $40 \%$ air saturation $\left(\sim 100 \mu \mathrm{mol} \mathrm{O}_{2} \mathrm{~L}^{-1}\right)$ and below. Accordingly, anaerobic nitrate turnover inside the aggregates was evident within this range of ambient oxygen levels. In incubations with ${ }^{15} \mathrm{~N}$-labeled nitrate, individual Skeletonema aggregates produced $\mathrm{NO}_{2}^{-}$(up to $10.7 \mathrm{nmol} \mathrm{N} \mathrm{h}{ }^{-1}$ per aggregate), $\mathrm{N}_{2}$ (up to $7.1 \mathrm{nmol} \mathrm{N} \mathrm{h}{ }^{-1}$ ), $\mathrm{NH}_{4}{ }^{+}$(up to $2.0 \mathrm{nmol} \mathrm{N} \mathrm{h}{ }^{-1}$ ), and $\mathrm{N}_{2} \mathrm{O}$ (up to $0.2 \mathrm{nmol} \mathrm{N} \mathrm{h}^{-1}$ ). Intriguingly, nitrate stored inside the diatom cells served as an additional, internal nitrate source for dinitrogen production, which may partially uncouple anaerobic nitrate turnover by diatom aggregates from direct ambient nitrate supply. Sinking diatom aggregates can contribute directly to fixed-nitrogen loss in low-oxygen environments in the ocean and vastly expand the ocean volume in which anaerobic nitrogen turnover is possible, despite relatively high ambient oxygen levels. Depending on the extent of intracellular nitrate consumption during the sinking process, diatom aggregates may also be involved in the long-distance export of nitrate to the deep ocean.

Keywords: marine snow, sinking diatom aggregates, fixed-nitrogen loss, low-oxygen environments, intracellular nitrate, microsensors, stable isotopes

\section{INTRODUCTION}

Marine snow comprises a variety of organic aggregates, larger than $500 \mu \mathrm{m}$ in diameter, that are suspended in the ocean's water column (Simon et al., 2002; Turner, 2015). Often formed in the photic surface layers, such aggregates sink down toward the seafloor and thereby mediate organic carbon export to the deep ocean (Shanks and Trent, 1980). Diatom aggregates that form in the wake of phytoplankton blooms represent a major component of marine snow and promote the mass sinking of algal biomass (Smetacek, 1985; Alldredge and Gotschalk, 1989; Thornton, 2002). Sinking aggregates also represent nutrient oases for pelagic microorganisms and thus are highly enriched in bacteria and protists compared to ambient water (Ploug et al., 1999; Grossart et al., 2003; 
Thiele et al., 2015). The plume of metabolites leaking out of sinking aggregates has a much larger diameter than the aggregate itself and thereby also affects the behavior and metabolism of diverse free-living organisms (Kiørboe et al., 2001; Azam and Malfatti, 2007; Stocker et al., 2008).

The individual aggregate represents a distinctive chemical microenvironment in the water column, often enriched in nutrients (Shanks and Trent, 1979; Kaltenböck and Herndl, 1992) and depleted in $\mathrm{O}_{2}$ (Alldredge and Cohen, 1987; Ploug et al., 1997). This microenvironment may trigger microbial processes that would otherwise not occur in the water column (Shanks and Reeder, 1993; Karl and Tilbrook, 1994). An oxygen-depleted (anoxic) center may develop inside sinking aggregates due to the respiration activity of the inhabiting microbial community. This phenomenon is more likely to occur in large aggregates (due to diffusion limitation) and at high respiration rates (due to organic matter reactivity; Jørgensen, 1977). Accordingly, anoxic centers have been directly traced with $\mathrm{O}_{2}$ microsensors only in relatively large organic aggregates, such as fecal pellets (Alldredge and Cohen, 1987), laboratory-made aggregates (Ploug et al., 1997; Ploug and Bergkvist, 2015), zooplankton carcasses (Glud et al., 2015), and cyanobacterial colonies (Paerl and Bebout, 1988; Klawonn et al., 2015). Even in such aggregates, anoxia may be short-lived due to carbon limitation (Ploug et al., 1997), the distribution of $\mathrm{O}_{2}$ may be patchy (Paerl and Bebout, 1988), and low-oxygen conditions may quickly alternate with high-oxygen conditions in photosynthetically active aggregates (Alldredge and Cohen, 1987). Conversely, at low ambient $\mathrm{O}_{2}$ levels, e.g., in hypoxic coastal regions and oceanic oxygen minimum zones (OMZs), smaller aggregate sizes and/or lower respiration rates are sufficient to promote the development of an anoxic center in sinking aggregates. Hence, a higher abundance of hypoxic and anoxic aggregates can be assumed to occur in low-oxygen than in high-oxygen environments (Ploug et al., 1997; Ploug, 2001; Klawonn et al., 2015).

The currently expanding low-oxygen environments in the ocean (Diaz and Rosenberg, 2008) are estimated to be responsible for $30-50 \%$ of the total oceanic fixed-nitrogen loss (DeVries et al., 2013). Sinking aggregates potentially increase the ocean volume in which fixed-nitrogen loss can occur even further. Nevertheless, sinking aggregates have still not been shown to directly contribute to this process, even though they are often suspected of providing suitable microenvironments for anaerobic nitrogen cycling (Jensen et al., 2011; Kalvelage et al., 2011; Dalsgaard et al., 2014). We hypothesize that the globally abundant diatom aggregates (Smetacek, 1985; Alldredge and Gotschalk, 1989; Kiørboe et al., 1998; Thornton, 2002; Villareal et al., 2011; Kemp and Villareal, 2013) host anaerobic nitrogen-cycle activities at ambient $\mathrm{O}_{2}$ levels that inhibit such activities in free-living microorganisms, i.e., at $\mathrm{O}_{2}$ concentrations of $1-20 \mu \mathrm{mol} \mathrm{L}^{-1}$ or higher (Kalvelage et al., 2011; Dalsgaard et al., 2014). Aggregates were produced in the laboratory using the ubiquitous, bloom-forming, and nitratestoring diatom Skeletonema marinoi. Sinking diatom aggregates were individually studied at different ambient $\mathrm{O}_{2}$ levels to reveal the microscale $\mathrm{O}_{2}$ distribution inside the aggregates with microsensors and their inorganic nitrogen turnover with isotopically labeled nitrate.

\section{MATERIALS AND METHODS}

\section{Skeletonema Aggregates}

Diatom aggregates were produced in the laboratory using cultured Skeletonema marinoi (CCMP1332, NCMA), natural seawater, and a plankton wheel. S. marinoi was cultured in F/2 medium plus silicate (Guillard and Ryther, 1962) prepared with filtered $(0.45 \mu \mathrm{m})$ and autoclaved coastal seawater from the Baltic Sea (Kerteminde, Denmark) adjusted from 15 psu up to 30 psu with $\mathrm{NaCl}$. The cultivation temperature was $14^{\circ} \mathrm{C}$ and the light:dark cycle was 10:14 h. For aggregate production, $50 \mathrm{~mL}$ of stationary-phase S. marinoi culture was mixed with $550 \mathrm{~mL}$ unfiltered coastal seawater from the same site and filled bubblefree into glass bottles. These aggregate production bottles were fixed to a plankton wheel (diameter: $60 \mathrm{~cm}$ ) and continuously rotated to keep the diatom cells in suspension and to make them collide with each other and with microbes and small particles suspended in the seawater and thereby form aggregates. Spherical aggregates of $1 \mathrm{~mm}$ in diameter formed within $24 \mathrm{~h}$ and grew to larger, mostly ellipsoidal aggregates within 3 days. The rotation speed of the plankton wheel was repeatedly adjusted to make sure that the growing aggregates were continuously sinking rather than colliding with the wall of the aggregate production bottle, which would promote the compaction of the aggregates (Jackson, 2015). The seawater in each bottle was quantitatively replaced by fresh, aerated seawater on a daily basis to compensate for drops in $\mathrm{O}_{2}$ and $\mathrm{NO}_{3}{ }^{-}$concentrations and to minimize bottle effects on the microbial community composition. The $\mathrm{NO}_{3}{ }^{-}$concentration in the unamended seawater was in the range of $0.1-13.7 \mu \mathrm{mol}$ $\mathrm{L}^{-1}\left(4.5 \mu \mathrm{mol} \mathrm{L}{ }^{-1}\right.$ on average). One day before experimentation with aggregates, the seawater was amended with $25 \mu \mathrm{mol} \mathrm{L}^{-1}$ ${ }^{14} \mathrm{NO}_{3}{ }^{-}$and the aggregate production bottles were wrapped in aluminum foil. This mimicked the shift in conditions that aggregates encounter when they sink out of the photic zone into the dark, nitrate-rich aphotic zone. Microsensor measurements and stable isotope experiments were made with 4-7 days old aggregates.

\section{Microsensor Profiling}

Oxygen concentration profiles were measured through the center of sinking Skeletonema aggregates using microsensors in a net-jet flow system (Ploug and Jørgensen, 1999). Forty-two microprofiles were measured in 39 replicate aggregates exposed to $15,40,70$, and/or $100 \%$ air saturation (AS) in coastal seawater adjusted to $25 \mathrm{\mu mol} \mathrm{L}^{-1} \mathrm{NO}_{3}{ }^{-}, 14^{\circ} \mathrm{C}$, and darkness. One single aggregate was profiled at all four AS levels in random order, whereas the remaining aggregates were profiled at one AS level only. Oxygen microsensors were constructed and calibrated as described before (Revsbech, 1989), mounted on a motor-driven micromanipulator, and used for profiling at $100 \mu \mathrm{m}$ increments.

\section{${ }^{15} \mathrm{~N}-$ Stable-Isotope Incubations}

Rates of $\mathrm{NO}_{3}{ }^{-}$turnover by single Skeletonema aggregates were determined by incubation in ${ }^{15} \mathrm{NO}_{3}{ }^{-}$-enriched seawater adjusted to different ambient $\mathrm{O}_{2}$ levels $(n=5-9)$. Control incubations without aggregates were run at each ambient $\mathrm{O}_{2}$ level $(n=3)$. 
All incubations were made at $14^{\circ} \mathrm{C}$ and in darkness. Gas-tight incubation vials (25-mL serum bottles) were filled with unfiltered seawater (see above) amended with $23 \mu \mathrm{mol} \mathrm{L}-1{ }^{15} \mathrm{NO}_{3}{ }^{-}(98$ atom $\%{ }^{15} \mathrm{~N}$; Sigma-Aldrich) and adjusted to AS levels of 0, 15, 40,70 , or $100 \%$ by flushing with the appropriate oxygen:helium mixture. Ellipsoidal aggregates with a short-axis length of at least $2.5 \mathrm{~mm}$ were selected from the aggregate production bottles and carefully picked with a glass tube. The length of the three axes of the aggregates was measured to $0.5 \mathrm{~mm}$ with a caliper. One aggregate was transferred into each of the incubation vials which were then sealed with a butyl rubber stopper. The incubation vials were wrapped in aluminum foil and rotated on the plankton wheel to keep the aggregates sinking. Oxygen measurements were made and samples for $\mathrm{N}$ analyses were withdrawn hourly for a total of $6 \mathrm{~h}$. Oxygen concentration was measured with optode spots (SensorSpot, Pyroscience, Germany) fixed to the inside of the incubation vials and an optical $\mathrm{O}_{2}$ meter (FireStingO $\mathrm{O}_{2}$, Pyroscience, Germany; Supplementary Figure $\mathrm{S} 1 \mathrm{C}$ ). For $\mathrm{N}$ analyses, a $2.5-\mathrm{mL}$ water sample was taken with a syringe inserted through the stopper (Supplementary Figure S1C). A second syringe filled with $2.5 \mathrm{~mL}$ seawater (with known $\mathrm{NO}_{3}{ }^{-}$and $\mathrm{O}_{2}$ concentrations) was inserted through the stopper and its content injected into the incubation vial while the first syringe was pulled up. To achieve efficient mixing, the reciprocal use of the two syringes was repeated twice. Care was taken not to destroy the aggregate during sampling. The $2.5-\mathrm{mL}$ water sample was split into $1.5 \mathrm{~mL}$ for $\mathrm{N}_{2}$ and $\mathrm{N}_{2} \mathrm{O}$ analyses and $1 \mathrm{~mL}$ for dissolved inorganic nitrogen (DIN) analyses. The $\mathrm{N}_{2}$ and $\mathrm{N}_{2} \mathrm{O}$ sample was quickly injected into a helium-flushed and half-evacuated 3-mL exetainer (Labco, Wycombe, UK) that contained $50 \mu \mathrm{L} \mathrm{ZnCl} 2(50 \% \mathrm{w} / \mathrm{v})$ to stop metabolic activities. The DIN sample was immediately frozen at $-20^{\circ} \mathrm{C}$.

Net turnover rates of $\mathrm{O}_{2}$ and $\mathrm{N}$ compounds $\left({ }^{15} \mathrm{~N}\right.$-labeled and total) were calculated from linear concentration changes during the incubation and corrected for the dilution due to repeated sampling (Supplementary Figure S3). Rates determined in control incubations without aggregates were subtracted from those determined in incubations with aggregates. Nitrite production indicated activity of dissimilatory nitrate reduction to nitrite, $\mathrm{NH}_{4}{ }^{+}$production indicated activity of dissimilatory nitrate reduction to ammonium (DNRA), and $\mathrm{N}_{2} \mathrm{O}$ and $\mathrm{N}_{2}$ production indicated denitrification activity. For $\mathrm{NO}_{3}{ }^{-}, \mathrm{NO}_{2}{ }^{-}$, $\mathrm{NH}_{4}{ }^{+}$, and $\mathrm{N}_{2}$, the turnover rates were calculated for the ${ }^{15} \mathrm{~N}$ - and ${ }^{14} \mathrm{~N}$-isotopes and the sum of them (i.e., total rates), whereas for $\mathrm{N}_{2} \mathrm{O}$ only total turnover rates could be calculated. Specifically, the $\mathrm{NO}_{3}{ }^{-}$total and ${ }^{15} \mathrm{NO}_{3}{ }^{-}$turnover rates were directly measured and the ${ }^{14} \mathrm{NO}_{3}{ }^{-}$turnover rate was obtained by subtraction. Production rates of $\mathrm{N}_{2}$ total, ${ }^{15} \mathrm{~N}-\mathrm{N}_{2}$, and ${ }^{14} \mathrm{~N}$ $\mathrm{N}_{2}$ were calculated from the directly measured ${ }^{29} \mathrm{~N}_{2}$ and ${ }^{30} \mathrm{~N}_{2}$ production rates assuming the principles of random isotope pairing in the absence of anammox in the freshly produced aggregates (Nielsen, 1992). Total $\mathrm{NH}_{4}{ }^{+}$production rates were calculated as the sum of the production rates of the heavy isotopes (measured directly) and the light isotopes (inferred) assuming that these two rates had the same ratio as the ${ }^{15} \mathrm{~N}-\mathrm{N}_{2}$ and ${ }^{14} \mathrm{~N}-\mathrm{N}_{2}$ production ratio. Total $\mathrm{NO}_{2}{ }^{-}$production rates were calculated assuming that ${ }^{14} \mathrm{NO}_{2}{ }^{-}$and ${ }^{15} \mathrm{NO}_{2}{ }^{-}$production rates had the same ratio as the ${ }^{14} \mathrm{NO}_{3}{ }^{-}$and ${ }^{15} \mathrm{NO}_{3}{ }^{-}$concentrations in the seawater.

\section{Intracellular Nitrate Analysis}

To determine the initial content of intracellular nitrate $\left(\mathrm{ICNO}_{3}\right)$, 20 aggregates from three aggregate production bottles were analyzed. Aggregates were sized as described above, transferred into pre-weighed sample tubes, and immediately frozen in liquid nitrogen to stop all metabolic activities. The aggregate and the adhering water were weighed in the sample tube and stored at $-20^{\circ} \mathrm{C}$. For $\mathrm{ICNO}_{3}$ extraction, the aggregate samples were exposed to three freeze-thaw cycles (Heisterkamp et al., 2012). Nitrate concentrations in the aggregate and seawater samples were measured as described below. The $\mathrm{ICNO}_{3}$ content of the aggregate was calculated from the $\mathrm{NO}_{3}{ }^{-}$concentrations in the aggregate sample and in the seawater. Per-diatom-cell $\mathrm{ICNO}_{3}$ concentrations were obtained from cell counts in aggregates and the average cell volume of S. marinoi (Kamp et al., 2011).

\section{Nitrogen Analyses}

Nitrate and nitrite were analyzed on an $\mathrm{NO}_{\mathrm{x}}$ analyzer (CLD 66s, Eco Physics) using the $\mathrm{VCl}_{3}$ and $\mathrm{NaI}$ reduction assay, respectively (Braman and Hendrix, 1989; Yang et al., 1997). Ammonium was analyzed with the salicylate method (Bower and Holm-Hansen, 1980). Isotopically labeled dinitrogen $\left({ }^{15} \mathrm{~N}\right.$ $\mathrm{N}_{2}$ ) was analyzed in the headspace of exetainer samples on a gas chromatography-isotopic ratio mass spectrometer (GCIRMS; Thermo Delta V Plus, Thermo Scientific) with the excess above natural abundance calculated according to Nielsen (1992). Nitrous oxide was analyzed in the same exetainers on a gas chromatograph (GC 7890, Agilent Technologies). Both the prior sampling of the headspace for ${ }^{15} \mathrm{~N}-\mathrm{N}_{2}$ analysis and the amount of nitrous oxide dissolved in the seawater were accounted for in the calculation of the total amount of nitrous oxide in the sample. ${ }^{15} \mathrm{~N}$-labeled $\mathrm{NO}_{3}{ }^{-}, \mathrm{NO}_{2}{ }^{-}$, and $\mathrm{NH}_{4}{ }^{+}$were analyzed with the cadmium/sulfamic acid, sulfamic acid, and hypobromite assay, respectively, followed by ${ }^{15} \mathrm{~N}-\mathrm{N}_{2}$ analysis on the GC-IRMS (Warembourg, 1993; McIlvin and Altabet, 2005; Füssel et al., 2012).

\section{RESULTS}

\section{Characteristics of the Aggregates}

Diatom aggregates were produced on a plankton wheel from axenic cultures of $S$. marinoi and the natural microbial community of coastal seawater (see sketch in Supplementary Figure S1A). Aggregates formed within 1-3 days, were ellipsoidal, had a smooth surface, and were dark brown (Supplementary Figure S1B). Aggregates used in ${ }^{15} \mathrm{NO}_{3}{ }^{-}$incubations had average dimensions of $6.1 \mathrm{~mm} \times 4.0 \mathrm{~mm} \times 3.0 \mathrm{~mm}$, resulting in an average volume of $42 \pm 24 \mathrm{~mm}^{3}$ ( $\pm \mathrm{SD}, n=36$ aggregates). The average sinking velocity of Skeletonema aggregates of this average volume was $1055 \pm 91 \mathrm{~m} \mathrm{~d}^{-1}$ ( $\pm \mathrm{SD}, n=10$ aggregates) as determined in a sedimentation column.

The microscale $\mathrm{O}_{2}$ distribution inside dark-incubated, sinking Skeletonema aggregates was determined with $\mathrm{O}_{2}$ microsensors 
in a net-jet flow system (Ploug and Jørgensen, 1999). The microsensor profiles through the center of replicate aggregates revealed internal $\mathrm{O}_{2}$ concentrations that were always lower than the ambient $\mathrm{O}_{2}$ level (Figure 1, Supplementary Figure S2). Anoxic conditions in the center of a representative aggregate prevailed at ambient $\mathrm{O}_{2}$ concentrations that corresponded to 15 and $40 \%$ AS in the seawater (30 psu, $14^{\circ} \mathrm{C}$; Figure 1). A large number of $\mathrm{O}_{2}$ microprofiles measured at 70 and $100 \%$ AS revealed a correlation between internal and ambient $\mathrm{O}_{2}$ concentration, according to which anoxia inside the diatom aggregates studied here was expected at $40 \%$ AS (i.e., $\sim 100 \mu \mathrm{mol}$ $\mathrm{O}_{2} \mathrm{~L}^{-1}$ ) and below (Supplementary Figure S2).

\section{Nitrate Turnover at Different Ambient Oxygen Levels}

The potential for dissimilatory nitrate reduction (DNR) activity of Skeletonema aggregates was tested at five ambient $\mathrm{O}_{2}$ levels by tracing the fate of ${ }^{15} \mathrm{NO}_{3}{ }^{-}$in short-term incubations (Supplementary Figures S1A,C). Thirty-six handpicked Skeletonema aggregates with a short-axis length of $>2.5 \mathrm{~mm}$ were individually incubated in sealed glass vials that were mounted on a plankton wheel to simulate the sinking of the aggregates out of the photic zone (light, oxygen-rich, nitrate-poor) into the aphotic zone (dark, oxygen-poor, nitrate-rich). Concentration changes of $\mathrm{NO}_{3}{ }^{-}, \mathrm{NO}_{2}{ }^{-}, \mathrm{NH}_{4}{ }^{+}$, $\mathrm{N}_{2} \mathrm{O}$, and $\mathrm{N}_{2}$, and the isotopic composition of these species were monitored for $6 \mathrm{~h}$ at $14^{\circ} \mathrm{C}$. Stable $\mathrm{O}_{2}$ concentrations (Supplementary Figure S3A) were maintained by adjusting the $\mathrm{O}_{2}$ concentration in the refilled seawater at every

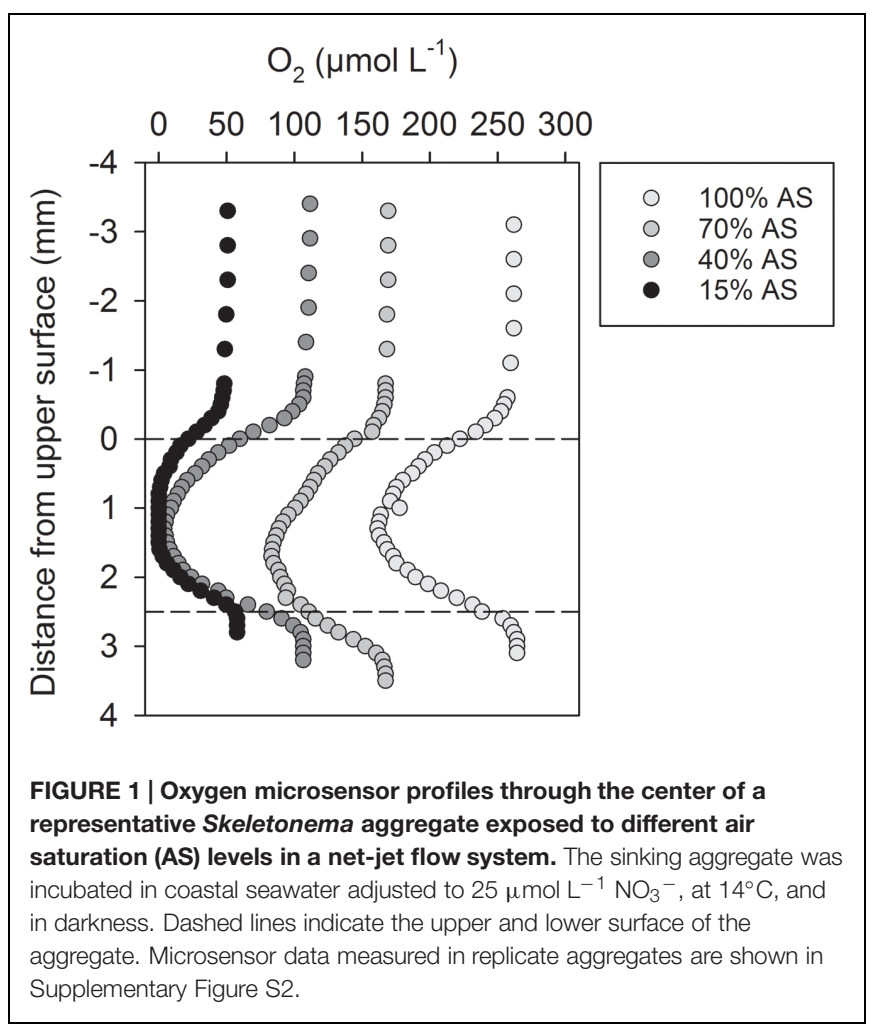

sampling occasion according to measurements with an $\mathrm{O}_{2}$ optode fixed to the inside of the vials (Supplementary Figure $\mathrm{S} 1 \mathrm{C})$.

Oxygen (when present) and $\mathrm{NO}_{3}{ }^{-}$were consumed at all ambient $\mathrm{O}_{2}$ levels tested (Figures 2A,B) with the consumption rates not being significantly affected by the ambient $\mathrm{O}_{2}$ level (Supplementary Table S1). In contrast, DNR activities of the aggregates, measured as net production rates of $\mathrm{NO}_{2}{ }^{-}, \mathrm{NH}_{4}{ }^{+}$, $\mathrm{N}_{2} \mathrm{O}$, and $\mathrm{N}_{2}$, were significantly affected by the ambient $\mathrm{O}_{2}$ level (Figures 2C-F, Supplementary Table S1). High production rates were only measured at ambient $\mathrm{O}_{2}$ levels corresponding to $0-40 \%$ AS. At $70-100 \%$ AS, the production rates were generally low and sometimes not significantly different from zero (Supplementary Table S2).

A mass balance of $\mathrm{NO}_{3}{ }^{-}$consumption (freely dissolved ${ }^{14} \mathrm{NO}_{3}{ }^{-}$and ${ }^{15} \mathrm{NO}_{3}{ }^{-}$) was made based on the production rates of $\mathrm{NO}_{2}{ }^{-}, \mathrm{NH}_{4}{ }^{+}, \mathrm{N}_{2} \mathrm{O}$, and $\mathrm{N}_{2}$. On average, the combined production of these $\mathrm{N}$ compounds amounted to 86,72, and $34 \%$ of $\mathrm{NO}_{3}{ }^{-}$consumption at 0,15 , and $40 \%$ AS, respectively (Figure 2G). Nitrite and $\mathrm{N}_{2}$ were quantitatively the most important products of $\mathrm{NO}_{3}{ }^{-}$consumption, with a clear $\mathrm{NO}_{2}{ }^{-}$ dominance at $0 \%$ AS and about equal shares at 15 and $40 \%$ AS. At $70-100 \%$ AS, however, only a minor fraction of the $\mathrm{NO}_{3}{ }^{-}$ consumed in the incubations was retrieved as $\mathrm{NO}_{2}{ }^{-}, \mathrm{NH}_{4}{ }^{+}$, $\mathrm{N}_{2} \mathrm{O}$, or $\mathrm{N}_{2}$ (Figure 2G). Thus, DNR activities explained the biggest proportion of $\mathrm{NO}_{3}{ }^{-}$consumption (up to $14.7 \mathrm{nmol}$ aggregate $^{-1} \mathrm{~h}^{-1}$ ) at low ambient $\mathrm{O}_{2}$ levels, whereas other processes (e.g., $\mathrm{NO}_{3}{ }^{-}$storage and assimilation) were relatively more important at high ambient $\mathrm{O}_{2}$ levels.

Nitrification activity of Skeletonema aggregates was assessed from temporal changes in the ${ }^{14} \mathrm{NO}_{3}{ }^{-} /{ }^{15} \mathrm{NO}_{3}{ }^{-}$ concentration ratio. No consistent trend of increasing ${ }^{14} \mathrm{NO}_{3}{ }^{-} /{ }^{15} \mathrm{NO}_{3}{ }^{-}$concentration ratios (which would indicate ${ }^{14} \mathrm{NO}_{3}{ }^{-}$release from the aggregates due to nitrification activity) was observed (Supplementary Figure S4). Instead, the residuals of a linear regression of the ${ }^{14} \mathrm{NO}_{3}{ }^{-} /{ }^{15} \mathrm{NO}_{3}{ }^{-}$ concentration ratios at $t_{0 \mathrm{~h}}$ vs. $t_{6 \mathrm{~h}}$ were normally distributed, indicating analytical noise. Nitrification rates as low as 0.1 nmol $\mathrm{NO}_{3}^{-} \mathrm{h}^{-1}$ per aggregate would be detected with this approach. It can thus not be ruled out that individual aggregates exhibited nitrification activity lower than that rate.

\section{Diffusion Limitation of Oxygen and Nitrate Consumption}

The ${ }^{15} \mathrm{NO}_{3}{ }^{-}$incubations at different $\mathrm{O}_{2}$ levels covered a considerable size range of aggregates (i.e., $16-132 \mathrm{~mm}^{3}$ ). Volumetric rates of $\mathrm{O}_{2}$ and $\mathrm{NO}_{3}{ }^{-}$consumption calculated from individual aggregate volumes and per-aggregate rates (i.e., rates in aggregate incubations minus rates in control incubations; Figures 2A,B) were significantly, negatively correlated with the equivalent spherical radius of the aggregates (Supplementary Figures S5A,B). The corresponding power functions had exponents of -2.3 and -2.6 for $\mathrm{O}_{2}$ and $\mathrm{NO}_{3}{ }^{-}$, respectively, in the ellipsoidal aggregates and were thus close to the theoretical exponent of -2 for diffusion-limited solute uptake by spherical 


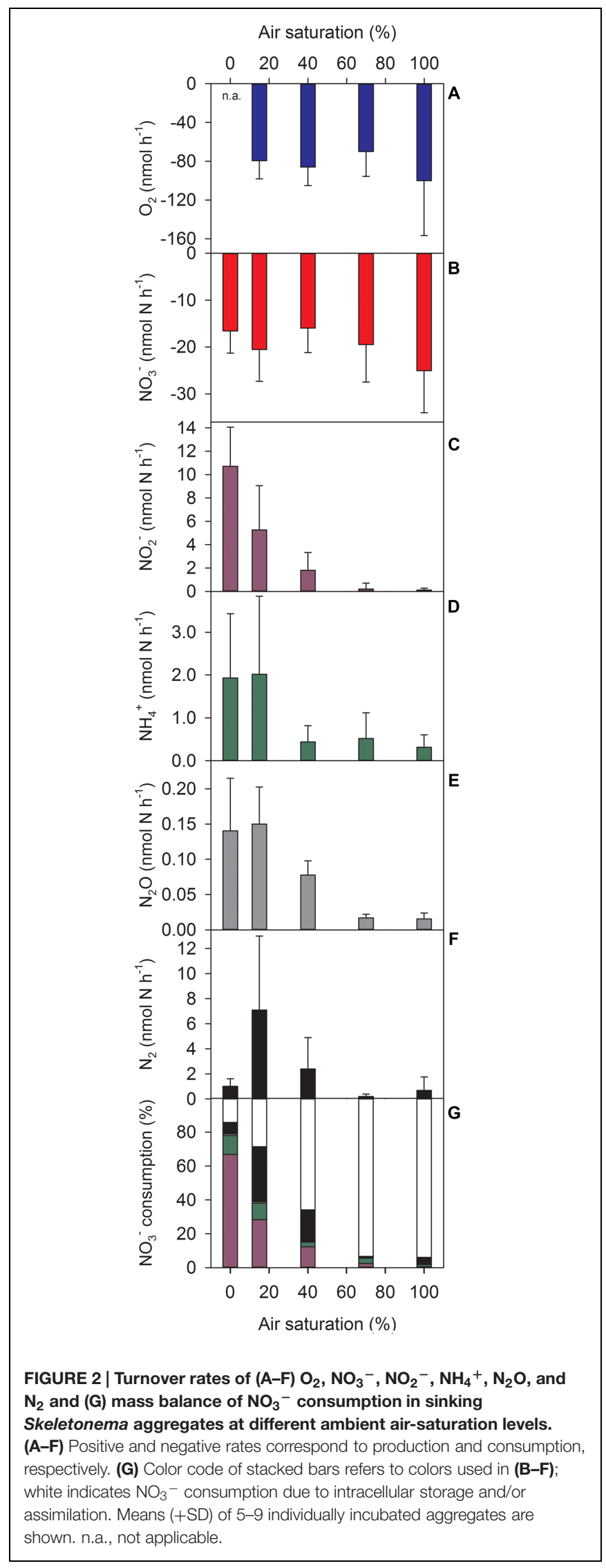

aggregates (Jørgensen, 1977; Schramm et al., 1999). Hence, solute transport inside the sinking diatom aggregates occurred through diffusion rather than advection.

\section{Internal Nitrate Availability}

Aside from the added ${ }^{15} \mathrm{NO}_{3}{ }^{-}$, the incubations contained low amounts of ${ }^{14} \mathrm{NO}_{3}{ }^{-}$freely dissolved in the seawater. Strikingly though, the ${ }^{14} \mathrm{~N}-\mathrm{N}_{2} /{ }^{15} \mathrm{~N}-\mathrm{N}_{2}$ concentration ratios were much higher throughout the incubations than the ${ }^{14} \mathrm{NO}_{3}{ }^{-} /{ }^{15} \mathrm{NO}_{3}{ }^{-}$concentration ratio (Supplementary Figure S6). The excess ${ }^{14} \mathrm{~N}-\mathrm{N}_{2}$ production deduced from this observation hints to the presence of an additional ${ }^{14} \mathrm{NO}_{3}{ }^{-}$source inside the aggregates. The time course of the ${ }^{14} \mathrm{~N}-\mathrm{N}_{2} /{ }^{15} \mathrm{~N}-\mathrm{N}_{2}$ concentration ratios further suggests an early phase of consumption of ${ }^{14} \mathrm{NO}_{3}{ }^{-}$that is already present inside the aggregate at the beginning of the incubation and a later phase of consumption of ${ }^{14} \mathrm{NO}_{3}{ }^{-}$that is generated or released into the aggregate during the incubation (Supplementary Figure S6C). Since S. marinoi is known to store $\mathrm{NO}_{3}{ }^{-}$in their cells (Kamp et al., 2011), intracellular nitrate $\left(\mathrm{ICNO}_{3}\right)$ was analyzed in 20 freshly produced Skeletonema aggregates. The total $\mathrm{ICNO}_{3}$ contents amounted to 4-45 nmol $\mathrm{N}$ aggregate ${ }^{-1}$, correlated well with aggregate volume (Figure $\mathbf{3 A}$ ), and corresponded to volumetric $\mathrm{ICNO}_{3}$ concentrations of $0.4-1.3 \mu \mathrm{mol} \mathrm{N} \mathrm{cm}{ }^{-3}$, with higher concentrations in smaller aggregates (Figure 3B). The corresponding per-diatom-cell concentrations were $39-59 \mathrm{mmol} \mathrm{ICNO}_{3} \mathrm{~L}^{-1}$. These $\mathrm{ICNO}_{3}$ concentrations were measured 4-7 days after the washed diatom cells had been transferred from culture medium (with initially $1 \mathrm{mmol} \mathrm{NO}_{3}^{-} \mathrm{L}^{-1}$ ) into natural seawater (with 0.1-13.7 $\mu \mathrm{mol} \mathrm{NO}_{3}{ }^{-} \mathrm{L}^{-1}$ ) and thus likely reflect

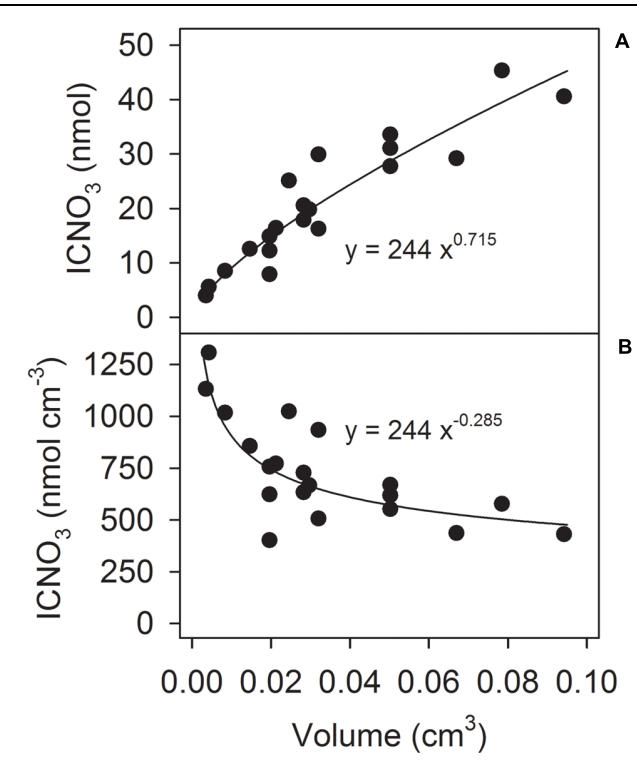

FIGURE 3 | Correlation between aggregate volume and (A) $\mathrm{ICNO}_{3}$ content and (B) $\mathrm{ICNO}_{3}$ concentration (per aggregate volume) in 20 freshly produced Skeletonema aggregates. 
$\mathrm{ICNO}_{3}$ levels that $S$. marinoi maintains at low ambient $\mathrm{NO}_{3}{ }^{-}$concentrations. Furthermore, the ${ }^{15} \mathrm{~N}$-stable-isotope enrichment experiments were not compromised by the $\mathrm{ICNO}_{3}$ present at the onset of the incubations. Even the maximum total $\mathrm{ICNO}_{3}$ content of $56 \mathrm{nmol}$ estimated for one of the aggregates used for ${ }^{15} \mathrm{NO}_{3}{ }^{-}$incubation decreased the labeling percentage of $\mathrm{NO}_{3}{ }^{-}$in the incubation bottle only from 87 to $80 \%$ and thus still allowed high-quality isotopic $\mathrm{N}_{2}$ analysis.

Using the regression equation presented in Figure 3B, the initial $\mathrm{ICNO}_{3}$ concentration of each ${ }^{15} \mathrm{NO}_{3}{ }^{-}$-incubated aggregate was estimated. The excess ${ }^{14} \mathrm{~N}-\mathrm{N}_{2}$ production (i.e., the difference between the measured ${ }^{14} \mathrm{~N}-\mathrm{N}_{2}$ production rate and the ${ }^{14} \mathrm{~N}-\mathrm{N}_{2}$ production rate predicted from the initial ${ }^{14} \mathrm{NO}_{3}{ }^{-} /{ }^{15} \mathrm{NO}_{3}{ }^{-}$concentration ratio) was significantly, positively correlated with the initial estimated $\mathrm{ICNO}_{3}$ concentration of the aggregates (Figure 4). Consumption rates of $\mathrm{ICNO}_{3}$ estimated from the excess ${ }^{14} \mathrm{~N}-\mathrm{N}_{2}$ production rates were very low with $0.23-0.27$ nmol $\mathrm{N}$ aggregate ${ }^{-1} \mathrm{~h}^{-1}$ at $0-40 \%$ AS and only $0.06 \mathrm{nmol} \mathrm{N}$ aggregate ${ }^{-1} \mathrm{~h}^{-1}$ at $70-$ $100 \%$ AS. The amount of $\mathrm{ICNO}_{3}$ consumed during the 6-h incubation at $0-40 \%$ AS corresponded to only $6.2-10.8 \%$ of the estimated initial $\mathrm{ICNO}_{3}$ contents. It cannot be ruled out that $\mathrm{ICNO}_{3}$ was also actively stored following the stepup of ambient $\mathrm{NO}_{3}{ }^{-}$concentration at the beginning of the incubations, especially at the high ambient $\mathrm{O}_{2}$ levels, where it would have contributed to the large fraction of $\mathrm{NO}_{3}{ }^{-}$consumption not accounted for by DNR activities (Figures 2B,G).

\section{DISCUSSION}

\section{Diatom Aggregates Host Anaerobic Nitrogen-Cycle Pathways}

The aggregates produced from the ubiquitous diatom $S$. marinoi showed high DNR rates at ambient $\mathrm{O}_{2}$ levels that were 1-2 orders of magnitude higher than inhibitory

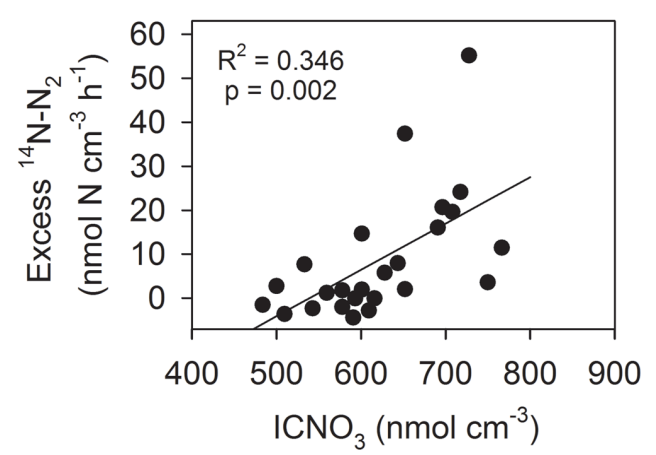

FIGURE 4 | Correlation between estimated initial ICNO ${ }_{3}$ concentration and excess ${ }^{14} \mathrm{~N}-\mathrm{N}_{2}$ production rate (i.e., the difference between measured and predicted ${ }^{14} \mathrm{~N}-\mathrm{N}_{2}$ production) in 25 Skeletonema aggregates incubated with ${ }^{15} \mathrm{NO}_{3}{ }^{-}$at $0-40 \%$ air saturation. levels for DNR by free-living microorganisms (Kalvelage et al., 2011; Dalsgaard et al., 2014). Significant DNR rates were measured at ambient $\mathrm{O}_{2}$ concentrations $\leq 100 \mu \mathrm{mol}$ $\mathrm{L}^{-1}$ (i.e., $40 \% \mathrm{AS}$ ), at and below which anoxic conditions prevailed in the center of the aggregates, as confirmed with microsensor measurements (Figure 1, Supplementary Figure S2). Community respiration inside the aggregates thus exceeded the supply of $\mathrm{O}_{2}$ from the surrounding water (Jørgensen, 1977; Ploug et al., 1997; Ploug and Bergkvist, 2015). As a consequence, facultative anaerobic microorganisms (prokaryotes and/or eukaryotes) inside the aggregates must have switched from aerobic respiration to DNR processes. Products and intermediates of these DNR processes were released into the surrounding water. Natural diatom aggregates with similar characteristics thus have the potential to contribute to fixed-nitrogen loss (as $\mathrm{N}_{2}$ ), directly through denitrification and indirectly by supplying $\mathrm{NO}_{2}^{-}$and $\mathrm{NH}_{4}{ }^{+}$for anammox, and to greenhouse gas production (as $\mathrm{N}_{2} \mathrm{O}$ ) in the water column of the ocean, even at relatively high ambient $\mathrm{O}_{2}$ levels.

Dissimilatory nitrate reduction was not the only significant $\mathrm{NO}_{3}{ }^{-}$sink in Skeletonema aggregates. The relative share of DNR in $\mathrm{NO}_{3}{ }^{-}$consumption decreased gradually from $\sim 85 \%$ to $\sim 5 \%$ with the ambient $\mathrm{O}_{2}$ level increasing from 0 to $100 \%$ AS (Figure 2G). The unaccounted fraction of $\mathrm{NO}_{3}{ }^{-}$consumption was probably due to cellular uptake and storage and/or assimilation of $\mathrm{NO}_{3}^{-}$. Many diatoms, including S. marinoi, store $\mathrm{NO}_{3}{ }^{-}$intracellularly at concentrations by far exceeding ambient levels, mostly for assimilatory or dissimilatory use (Lomas and Glibert, 2000; Kamp et al., 2011, 2015). Intracellular nitrate $\left(\mathrm{ICNO}_{3}\right)$ analysis in our Skeletonema aggregates revealed total contents of 4-45 nmol $\mathrm{ICNO}_{3}$ per aggregate, whereas the $\mathrm{NO}_{3}{ }^{-}$consumption unaccounted for by DNR amounted to 14-141 nmol $\mathrm{NO}_{3}{ }^{-}$at the end of the 6-h incubations at 0$100 \%$ AS. Thus, a substantial fraction of non-dissimilatory $\mathrm{NO}_{3}{ }^{-}$ consumption might be due to $\mathrm{ICNO}_{3}$ storage by $S$. marinoi, and the rest must be ascribed to $\mathrm{NO}_{3}{ }^{-}$assimilation by the microbial community of the aggregate.

Nitrite was quantitatively the most important product of DNR released from Skeletonema aggregates, followed by $\mathrm{N}_{2}$, $\mathrm{NH}_{4}{ }^{+}$, and $\mathrm{N}_{2} \mathrm{O}$. In natural marine snow, $\mathrm{NO}_{2}{ }^{-}$and $\mathrm{NH}_{4}{ }^{+}$ concentrations are significantly higher than in the ambient water (Shanks and Trent, 1979; Kaltenböck and Herndl, 1992), which in the light of our results might be due to aggregate-associated DNR. In contrast, $\mathrm{NO}_{3}{ }^{-}$concentrations in natural marine snow are not consistently higher than ambient concentrations and sometimes even lower (Shanks and Trent, 1979; Alldredge and Gotschalk, 1989; Kaltenböck and Herndl, 1992). Lower $\mathrm{NO}_{3}{ }^{-}$concentrations in aggregates are consistent with DNR activities, whereas higher $\mathrm{NO}_{3}{ }^{-}$concentrations may result from nitrification activity, but also from $\mathrm{NO}_{3}{ }^{-}$measurements that include the intracellular $\mathrm{NO}_{3}{ }^{-}$stores of diatoms because of cell leakage during sample preservation or processing.

Nitrite rather than $\mathrm{N}_{2}$ was the main product of DNR also at $0 \%$ AS. In OMZs, $\mathrm{NO}_{2}{ }^{-}$accumulation due to DNR is frequently observed at high $\mathrm{NO}_{3}{ }^{-}$concentrations (Lam 
et al., 2011; Kalvelage et al., 2013; Ganesh et al., 2015). The ambient $\mathrm{NO}_{3}{ }^{-}$concentration in our incubations of $\sim 25 \mu \mathrm{mol}$ $\mathrm{L}^{-1}$ corresponds to the high $\mathrm{NO}_{3}{ }^{-}$concentrations typically encountered in OMZs (Anderson et al., 1982; Ganesh et al., 2015). However, the inverse relationship between the volumetric consumption rate of ambient $\mathrm{NO}_{3}{ }^{-}$and the aggregate radius suggested diffusional $\mathrm{NO}_{3}{ }^{-}$limitation inside the aggregate (Schramm et al., 1999). Therefore, $\mathrm{N}_{2}$ rather than $\mathrm{NO}_{2}{ }^{-}$ was the expected end product of aggregate-associated DNR, as is the case in marine sediments with diffusional $\mathrm{NO}_{3}{ }^{-}$ limitation in the denitrification layer (Devol, 2015). It may be speculated, however, that the $\mathrm{ICNO}_{3}$ pool of the densely packed diatoms in the aggregates, if released into the aggregate due to microbial attack and cell lysis, will abolish this $\mathrm{NO}_{3}{ }^{-}$limitation and promote $\mathrm{NO}_{3}{ }^{-}$reduction to $\mathrm{NO}_{2}{ }^{-}$ only.

The negligible aggregate-associated nitrification activity is surprising because $\mathrm{NH}_{4}{ }^{+}$was not quantitatively released into the surrounding water. Only at low ambient $\mathrm{O}_{2}$ levels (0 and $15 \%$ AS), about half of the aggregates released significant amounts of $\mathrm{NH}_{4}{ }^{+}$. Theoretical $\mathrm{NH}_{4}{ }^{+}$production rates estimated from the measured rates of $\mathrm{O}_{2}$ consumption and DNR (and assuming degradation of 'Redfieldian' organic matter) amount to $\sim 10-15 \mathrm{nmol} \mathrm{NH}_{4}{ }^{+} \mathrm{h}^{-1}$, which should lead to a substantial $\mathrm{NH}_{4}{ }^{+}$release in the absence of nitrification. An alternative sink for $\mathrm{NH}_{4}{ }^{+}$inside the aggregates may have been $\mathrm{NH}_{4}{ }^{+}$ assimilation by diatoms and bacteria. If nitrification activity was mainly located close to the oxic-anoxic interface inside the aggregate, then part of the newly produced ${ }^{14} \mathrm{NO}_{3}{ }^{-}$would have diffused into the anoxic core and contributed to the production of ${ }^{14} \mathrm{~N}-\mathrm{N}_{2}$. The excess ${ }^{14} \mathrm{~N}-\mathrm{N}_{2}$ production, however, was as low as $0.23-0.27 \mathrm{nmol} \mathrm{N} \mathrm{h}^{-1}$ and was significantly correlated with the $\mathrm{ICNO}_{3}$ concentration of the aggregates. Additionally, there is no evidence for $\mathrm{NH}_{4}{ }^{+}$consumption in the subsurface layer or for $\mathrm{NH}_{4}{ }^{+}$limitation in the oxic surface layer of the aggregates provided by microsensor measurements. Low or negligible nitrification rates were also measured in natural cyanobacterial and laboratory-made diatom aggregates (Klawonn et al., 2015; Ploug and Bergkvist, 2015). The generally low growth rates of nitrifying microorganisms may delay the colonization of short-lived sinking aggregates. Moreover, nitrifiers might be outcompeted by heterotrophic bacteria inside the organic-carbon-rich aggregates (Strauss and Lamberti, 2000).

\section{Conceptual Model of Nitrogen Cycling in Diatom Aggregates}

Marine snow is highly enriched in microbial biomass, exceeding ambient densities by three orders of magnitude (Ploug et al., 1999; Grossart et al., 2003; Thiele et al., 2015). Nevertheless, at total aggregate volumes of only a few $\mathrm{cm}^{3}$ per $\mathrm{m}^{3}$ water, the aggregate-associated microbial biomass makes up only little of the total microbial biomass (Thiele et al., 2015). It is thus much more the spatial structure of this concentrated biomass by which sinking aggregates leave their mark on oceanic water-column biogeochemistry. Physical, chemical, and biological gradients inside the aggregates persist within a relatively homogeneous macroenvironment. This microscale gradient system allows metabolic activities that otherwise would not occur in the water column, obviously also anaerobic nitrogen cycling at otherwise inhibitory ambient $\mathrm{O}_{2}$ levels. The diatom aggregates used in this study had sufficient size and respiration rates to sustain an anoxic center even at intermediate $\mathrm{O}_{2}$ levels in the ambient water (Figure 5). In spherical or ellipsoidal aggregates in which diffusional solute exchange dominates, a near-concentric arrangement of aggregate surface, oxic-anoxic interface, and $\mathrm{NO}_{3}{ }^{-}$penetration depth may establish (Klawonn et al., 2015). We propose that DNR activity proceeds just below the oxic-anoxic interface inside diatom aggregates.

Our experiments with sinking diatom aggregates also revealed that DNR activities can be uncoupled from ambient $\mathrm{NO}_{3}{ }^{-}$ supply due to the $\mathrm{ICNO}_{3}$ stores of the aggregate-associated diatoms. Based on the estimates obtained in these experiments, the $\mathrm{ICNO}_{3}$ stores of lysing diatom cells may sustain DNR activities of the microbial community of the aggregates for 54$96 \mathrm{~h}$, thus for most of the sinking period of natural aggregates even through deep parts of the ocean. In contrast, DNRA activity of living diatom cells exposed to anoxic conditions inside the aggregates may only last for a few hours until the $\mathrm{ICNO}_{3}$ stores are used up (Kamp et al., 2011). Depending on the $\mathrm{ICNO}_{3}$ consumption rate, sinking velocity, and water depth, diatom aggregates will export a so far unquantified amount of $\mathrm{NO}_{3}{ }^{-}$to deep water layers or even the sea floor. Fast-sinking aggregates may deliver $\mathrm{ICNO}_{3}$ all the way to the seafloor where microbial degradation of the aggregates can be expected to create anoxic microsites in otherwise oxic sediments and liberate $\mathrm{NO}_{3}{ }^{-}$as

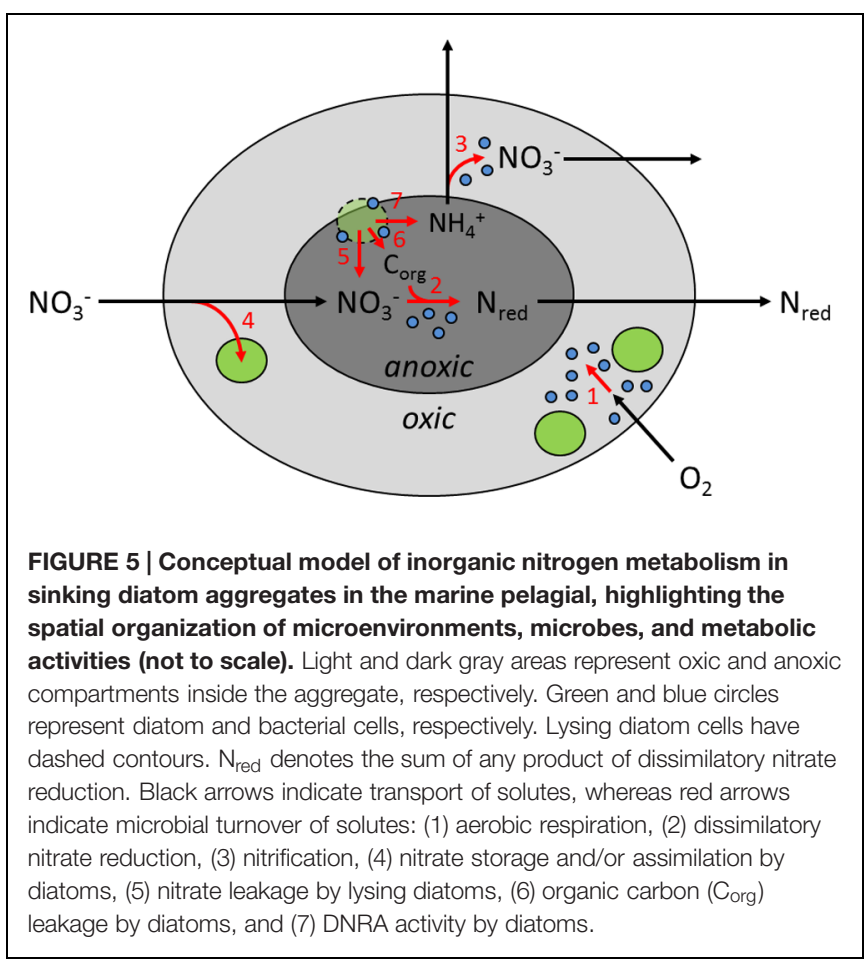


well as labile organic carbon from lysing diatom cells (Glud, 2008). Settled aggregates are therefore thought to stimulate benthic denitrification and other DNR processes (Lehto et al., 2014).

We hypothesize that diatoms contribute to DNR activities in marine snow, both directly and indirectly (Figure 5): (1) Diatoms near the surface of the aggregate take up and store $\mathrm{NO}_{3}{ }^{-}$under oxic conditions in photic water layers and thereby contribute to overall $\mathrm{NO}_{3}{ }^{-}$consumption by the aggregate. (2) Under dark conditions, diatoms near the oxic-anoxic interface within the aggregate use their $\mathrm{ICNO}_{3}$ stores for DNRA and thereby directly contribute to DNR by the aggregate. (3) In the anoxic center of the aggregates, diatom cells lyse and release $\mathrm{ICNO}_{3}$ into the aggregate (and potentially also labile organic matter), which fuels DNR by the microbial community of the aggregate. Diatom aggregates thus release $\mathrm{NH}_{4}{ }^{+}$through both the mineralization of organic matter (Ploug and Bergkvist, 2015) and the DNRA activity of the diatoms (Kamp et al., 2011, 2013). In OMZs, diatom aggregates may therefore play a key role by supplying $\mathrm{NH}_{4}{ }^{+}$to the anammox process, a still debated issue (Dalsgaard et al., 2012; Kalvelage et al., 2013; Babbin et al., 2014).

Microbial nitrogen cycling associated with marine snow apparently differs between diatom and cyanobacterial aggregates. Denitrification was not detected in ${ }^{15} \mathrm{~N}$-stableisotope incubations of deoxygenated cyanobacterial biomass enriched from a bloom in the Baltic Sea during which aggregates were observed (Hietanen et al., 2002). Negligible denitrification activity was measured in ${ }^{15} \mathrm{~N}$-stable-isotope incubations of intact cyanobacterial aggregates (Nodularia sp.) collected in the Baltic Sea and incubated under oxic conditions, despite the presence of denitrification genes (Tuomainen et al., 2003) and anoxic centers in the aggregates as measured with microsensors (Klawonn et al., 2015). In contrast, DNRA rates were similarly high in cyanobacterial aggregates (Klawonn et al., 2015) as in the Skeletonema aggregates. The reasons for the insignificance of denitrification, but not DNRA, in cyanobacterial aggregates are currently not known.

\section{Ecological Implications of Nitrogen Cycling in Diatom Aggregates}

The diatom aggregates studied here had sinking velocities in the upper range of what has been reported for other marine aggregates (Diercks and Asper, 1997; Ploug et al., 2008; Villareal et al., 2011; Turner, 2015). Diatom aggregates produced in the laboratory may reach sinking velocities $>800 \mathrm{~m} \mathrm{~d}^{-1}$ (Ziervogel and Forster, 2005; Iversen and Ploug, 2013), whereas natural diatom aggregates have sinking velocities of $50-200 \mathrm{~m} \mathrm{~d}^{-1}$ (Alldredge and Gotschalk, 1989; Ploug et al., 2008) or sometimes $500 \mathrm{~m} \mathrm{~d}^{-1}$ (Iversen and Ploug, 2010). High sinking velocities result from a dense packing of organic matter, microbial biomass, and ballast materials (Ploug et al., 2008). The ensuing high mineralization and respiration rates inside compact aggregates cause steep $\mathrm{O}_{2}$ concentration gradients, which makes anoxia and DNR activity more likely to occur inside the aggregate. In contrast, high sinking velocities decrease the thickness of the surrounding diffusive boundary layer at the upstream side of the aggregate and thereby potentially increase the $\mathrm{O}_{2}$ flux to the aggregate (Ploug, 2001; Ploug et al., 2008). As a consequence, the hypoxic or anoxic center of the aggregate can be shifted to the downstream side (Ploug et al., 1997) or may even disappear and render DNR activity unlikely. The question remains whether anoxia and DNR activity are also likely to occur in less compact and slower-sinking aggregates. Such "fluffy" aggregates probably possess lower respiration rates (anoxia less likely) and thicker diffusive boundary layers (anoxia more likely), but may also be affected by advective porewater flow (anoxia less likely). Importantly, the residence time of slow-sinking aggregates in deep, hypoxic or anoxic water layers is prolonged, which will increase time-integrated DNR rates. Studies on less compact and/or smaller aggregates concluded that internal anoxia should be common at $<20-25 \mu \mathrm{mol}$ $\mathrm{O}_{2} \mathrm{~L}^{-1}$ in the ambient water (Ploug, 2001; Klawonn et al., 2015).

The quantitative data on the relatively large and compact diatom aggregates used in this study cannot be directly extrapolated to any marine environment where smaller and less compact aggregates are exposed to high $\mathrm{O}_{2}$ levels. However, in the productive coastal upwelling regions adjacent to OMZs, the export flux of particulate organic carbon is high (MullerKarger et al., 2001; Chavez et al., 2011), dominated by diatom aggregates (Kiørboe et al., 1998; Wright et al., 2012), and ambient $\mathrm{O}_{2}$ levels are low. Approximately $0.08-0.11 \mathrm{~g} \mathrm{C} \mathrm{m}^{-2}$ $\mathrm{d}^{-1}$ reaches the anoxic water body within the Cariaco Basin (Muller-Karger et al., 2001). In the Peruvian upwelling system, 0.08-1.26 $\mathrm{g} \mathrm{C} \mathrm{m}^{-2} \mathrm{~d}^{-1}$ reaches the upper boundary of the Eastern Tropical South Pacific OMZ (Kalvelage et al., 2013). These carbon export fluxes would correspond to densities of 1.52.0 and 1.5-24 Skeletonema aggregates $\mathrm{m}^{-3}$, respectively (on the basis of average-sized aggregates with an organic carbon content of $50 \mu \mathrm{g}$ (estimated from Iversen and Ploug, 2013, Figure 3A and a sinking velocity of $1055 \mathrm{~m} \mathrm{~d}^{-1}$ ). Combining these ranges of aggregate densities, $\mathrm{N}_{2}$ production mediated by anoxic diatom aggregates would be equivalent to $0.13-2.04 \mathrm{nmol} \mathrm{N}_{2} \mathrm{~L}^{-1} \mathrm{~d}^{-1}$, which is at the lower end of fixed-nitrogen loss rates of 0 $90 \mathrm{nmol} \mathrm{N} \mathrm{L}_{2}^{-1} \mathrm{~d}^{-1}$ reported for OMZs (Lam and Kuypers, 2011). High rates are, however, typically restricted to the upper 50-100 $\mathrm{m}$ of the anoxic OMZ core, and thus the aggregateassociated rates would more likely constitute a substantial contribution deeper in the OMZs where $\mathrm{N}_{2}$ production is often not detectable in experimental incubations, which would typically not include the aggregates (Dalsgaard et al., 2012; Kalvelage et al., 2013).

During seasonal pulses of pelagic primary production like phytoplankton blooms and the ensuing mass sinking of aggregates (Smetacek, 1985; Thornton, 2002), aggregate densities in coastal regions can be as high as $0.1-15$ aggregates $\mathrm{L}^{-1}$ or $>1000$ times higher than the values calculated above (Knauer et al., 1982; Lampitt et al., 2001; Grossart et al., 2003). Additionally, natural diatom aggregates in coastal regions cover a size range of $0.16-523 \mathrm{~mm}^{3}$ (Grossart et al., 2003), meaning that large specimens can be $>10$ times bigger than an average-sized diatom aggregate of this study. At such high in situ densities 
and sizes, aggregate-associated DNR could in fact be even more significant than calculated above. However, experimentation with natural aggregates and modeling efforts accounting for variations in size and compactness of aggregates are needed to arrive at better estimates of the contribution of marine snow to DNR activities in the marine pelagic.

The quantitative importance of sinking diatom aggregates for pelagic DNR can also be assessed with respect to the total ocean volume in which DNR can potentially take place due to the presence of aggregates. Globally, the ocean volume with $\mathrm{O}_{2}$ concentrations $\leq 100 \mu \mathrm{mol} \mathrm{L}^{-1}$ (at which aggregate-associated DNR occurred in this study) is $>90$ times larger than the volume with $\leq 5 \mu \mathrm{mol} \mathrm{L}{ }^{-1}$ (at which DNR by free-living microbes is possible; Karstensen et al., 2008; Kalvelage et al., 2011; Dalsgaard et al., 2014). Even for the threshold concentration of 20-25 $\mu \mathrm{mol}$ $\mathrm{O}_{2} \mathrm{~L}^{-1}$ proposed to support anoxia in other studies (Ploug, 2001; Klawonn et al., 2015), this factor would still be $>20$. Thus, integrated over the oceans, aggregate-associated DNR is probably more important at the boundaries of OMZs than within their core. Even at relatively low bulk rates in these voluminous areas, aggregate-associated nitrogen turnover and fixed-nitrogen loss, in particular, could contribute substantially to oceanic nitrogen budgets.

\section{CONCLUSION}

The findings of this study provide a new conceptual basis for aggregate-scale to ecosystem-scale modeling and understanding of nitrogen cycling, especially in low-oxygen environments. Extending the existing models of pelagic nitrogen cycling by aggregate-related processes is essential for both the notorious and the emerging ecosystems with high aggregate densities, such as eutrophic coastal regions (Müller-Niklas et al., 1994), oceanic OMZs (Wright et al., 2012), Arctic waters impacted by sinking

\section{REFERENCES}

Alldredge, A. L., and Cohen, Y. (1987). Can microscale chemical patches persist in the sea? Microelectrode study of marine snow, fecal pellets. Science 235, 689-691. doi: 10.1126/science.235.4789.689

Alldredge, A. L., and Gotschalk, C. C. (1989). Direct observations of the mass flocculation of diatom blooms - characteristics, settling velocities and formation of diatom aggregates. Deep Sea Res. Part. A Oceanogr. Res. Papers 36, 159-171. doi: 10.1016/0198-0149(89)90131-3

Anderson, J. J., Okubo, A., Robbins, A. S., and Richards, F. A. (1982). A model for nitrite and nitrate distributions in oceanic oxygen minimum zones. Deep Sea Res. 29, 1113-1140. doi: 10.1016/0198-0149(82)90031-0

Azam, F., and Malfatti, F. (2007). Microbial structuring of marine ecosystems. Nat. Rev. Microbiol. 5, 782-791. doi: 10.1038/nrmicro1747

Babbin, A. R., Keil, R. G., Devol, A. H., and Ward, B. B. (2014). Organic matter stoichiometry, flux, and oxygen control nitrogen loss in the ocean. Science 344, 406-408. doi: 10.1126/science. 1248364

Bochdansky, A. B., van Aken, H. M., and Herndl, G. J. (2010). Role of macroscopic particles in deep-sea oxygen consumption. Proc. Natl. Acad. Sci. U.S.A. 107, 8287-8291. doi: 10.1073/pnas.0913744107

Boetius, A., Albrecht, S., Bakker, K., Bienhold, C., Felden, J., Fernández-Méndez, M., et al. (2013). Export of algal biomass from the melting Arctic sea ice. Science 339, 1430-1432. doi: 10.1126/science.1231346 aggregates of sea-ice algae (Boetius et al., 2013), and even the deep sea (Bochdansky et al., 2010). Since all of the aforementioned marine ecosystems are characterized by relatively high $\mathrm{NO}_{3}{ }^{-}$ concentrations, the contribution of sinking aggregates to fixednitrogen loss needs to be better constrained.

\section{AUTHOR CONTRIBUTIONS}

PS, RG, and BT designed the study. PS carried out the ${ }^{15} \mathrm{~N}$-labeling experiments. AK made the intracellular nitrate measurements. All authors interpreted the data. PS wrote the manuscript with input from all co-authors.

\section{FUNDING}

This study was financially supported by grants from FNU awarded to RG and BT (0602-02276B), and from the German Research Foundation awarded to AK (KA 3187/2-1).

\section{ACKNOWLEDGMENTS}

We would like to thank A. Glud for microsensor construction and measurements and L. A. Bristow, L. K. Robertson, M. Larsen, H. U. Riisgård, D. H. Skov, and D. de Beer for technical support. U. Marzocchi and A. S. Birch Lundgaard are acknowledged for fruitful discussions.

\section{SUPPLEMENTARY MATERIAL}

The Supplementary Material for this article can be found online at: http://journal.frontiersin.org/article/10.3389/fmicb. 2016.00098

Bower, C. E., and Holm-Hansen, T. (1980). A salicylate-hypochlorite method for determining ammonia in seawater. Can. J. Fish. Aquat. Sci. 37, 794-798. doi: 10.1139/f80-106

Braman, R. S., and Hendrix, S. A. (1989). Nanogram nitrite and nitrate determination in environmental and biological materials by vanadium(III) reduction with chemiluminescence detection. Anal. Chem. 61, 2715-2718. doi: 10.1021/ac00199a007

Chavez, F. P., Messie, M., and Pennington, J. T. (2011). Marine primary production in relation to climate variability and change. Annu. Rev. Mar. Sci. 3, 227-260. doi: 10.1146/annurev.marine.010908.163917

Dalsgaard, T., Stewart, F. J., Thamdrup, B., De Brabrandere, L., Revsbech, N. P., Ulloa, O., et al. (2014). Oxygen at nanomolar levels reversibly suppresses process rates and gene expression in anammox and denitrification in the oxygen minimum zone off Northern Chile. Mbio 5:e1966-e1914. doi: 10.1128/mBio. 01966-14

Dalsgaard, T., Thamdrup, B., Farias, L., and Revsbech, N. P. (2012). Anammox and denitrification in the oxygen minimum zone of the eastern South Pacific. Limnol. Oceanogr. 57, 1331-1346. doi: 10.4319/lo.2012.57. 5.1331

Devol, A. H. (2015). Denitrification, anammox, and $\mathrm{N}_{2}$ production in marine sediments. Annu. Rev. Mar. Sci. 7, 403-423. doi: 10.1146/annurev-marine010213-135040 
DeVries, T., Deutsch, C., Rafter, P. A., and Primeau, F. (2013). Marine denitrification rates determined from a global 3-D inverse model. Biogeosciences 10, 2481-2496. doi: 10.5194/bg-10-2481-2013

Diaz, R. J., and Rosenberg, R. (2008). Spreading dead zones and consequences for marine ecosystems. Science 321, 926-929. doi: 10.1126/science.1156401

Diercks, A. R., and Asper, V. L. (1997). In situ settling speeds of marine snow aggregates below the mixed layer: black Sea and Gulf of Mexico. Deep Sea Res. I 44, 385-398. doi: 10.1016/S0967-0637(96)00104-5

Füssel, J., Lam, P., Lavik, G., Jensen, M. M., Holtappels, M., Günther, M., et al. (2012). Nitrite oxidation in the Namibian oxygen minimum zone. ISME J. 6, 1200-1209. doi: 10.1038/ismej.2011.178

Ganesh, S., Bristow, L. A., Larsen, M., Sarode, N., Thamdrup, B., and Stewart, F. J. (2015). Size-fraction partitioning of community gene transcription and nitrogen metabolism in a marine oxygen minimum zone. ISME J. 9, 2682-2696. doi: 10.1038 /ismej.2015.44

Glud, R. N. (2008). Oxygen dynamics of marine sediments. Mar. Biol. Res. 4, 243-289. doi: 10.1080/17451000801888726

Glud, R. N., Grossart, H. P., Larsen, M., Tang, K. W., Arendt, K. E., Rysgaard, S., et al. (2015). Copepod carcasses as microbial hot spots for pelagic denitrification. Limnol. Oceanogr. 60, 2026-2036.

Grossart, H. P., Hietanen, S., and Ploug, H. (2003). Microbial dynamics on diatom aggregates in Øresund. Denmark. Mar. Ecol. Prog. Ser. 249, 69-78. doi: $10.3354 /$ meps 249069

Guillard, R. R., and Ryther, J. H. (1962). Studies of marine planktonic diatoms. 1. Cyclotella nana Hustedt, and Detonula confervacea (Cleve) Gran. Can. J. Microbiol. 8, 229-239. doi: 10.1139/m62-029

Heisterkamp, I. M., Kamp, A., Schramm, A. T., de Beer, D., and Stief, P. (2012). Indirect control of the intracellular nitrate pool of intertidal sediment by the polychaete Hediste diversicolor. Mar. Ecol. Prog. Ser. 445, 181-192. doi: 10.3354/meps09464

Hietanen, S., Moisander, P. H., Kuparinen, J., and Tuominen, L. (2002). No sign of denitrification in a Baltic Sea cyanobacterial bloom. Mar. Ecol. Prog. Ser. 242, 73-82. doi: 10.3354/meps242073

Iversen, M. H., and Ploug, H. (2010). Ballast minerals and the sinking carbon flux in the ocean: carbon-specific respiration rates and sinking velocity of marine snow aggregates. Biogeosciences 7, 2613-2624. doi: 10.5194/bg-7-2613-2010

Iversen, M. H., and Ploug, H. (2013). Temperature effects on carbon-specific respiration rate and sinking velocity of diatom aggregates - potential implications for deep ocean export processes. Biogeosciences 10, 4073-4085. doi: 10.5194/bg-10-4073-2013

Jackson, G. A. (2015). Coagulation in a rotating cylinder. Limnol. Oceanogr. Methods 13, 194-201.

Jensen, M. M., Lam, P., Revsbech, N. P., Nagel, B., Gaye, B., Jetten, M. S. M., et al. (2011). Intensive nitrogen loss over the Omani Shelf due to anammox coupled with dissimilatory nitrite reduction to ammonium. ISME J. 5, 1660-1670. doi: 10.1038/ismej.2011.44

Jørgensen, B. B. (1977). Bacterial sulfate reduction within reduced microniches of oxidized marine sediments. Mar. Biol. 41, 7-17. doi: 10.1007/BF00390576

Kaltenböck, E., and Herndl, G. J. (1992). Ecology of amorphous aggregations (marine snow) in the Northern Adriatic Sea: 4. Dissolved nutrients and the autotrophic community associated with marine snow. Mar. Ecol. Prog. Ser. 87, 147-159. doi: 10.3354/meps087147

Kalvelage, T., Jensen, M. M., Contreras, S., Revsbech, N.P., Lam, P., Günter, M., et al. (2011). Oxygen sensitivity of anammox and coupled $\mathrm{N}$-cycle processes in Oxygen Minimum Zones. PLoS ONE 6:e29299. doi: 10.1371/journal.pone.0029299

Kalvelage, T., Lavik, G., Lam, P., and others. (2013). Nitrogen cycling driven by organic matter export in the South Pacific oxygen minimum zone. Nat. Geosci. 6, 228-234. doi: 10.1038/ngeo1739

Kamp, A., de Beer, D., Nitsch, J. L., Lavik, G., and Stief, P. (2011). Diatoms respire nitrate to survive dark and anoxic conditions. Proc. Natl. Acad. Sci. U.S.A. 108, 5649-5654. doi: 10.1073/pnas.1015744108

Kamp, A., Høgslund, S., Risgaard-Petersen, N., and Stief, P. (2015). Nitrate storage and dissimilatory nitrate reduction by eukaryotic microbes. Front. Microbiol. 6:1492. doi: 10.3389/fmicb.2015.01492

Kamp, A., Stief, P., Knappe, J., and de Beer, D. (2013). Response of the ubiquitous pelagic diatom Thalassiosira weissflogii to darkness and anoxia. PLoS ONE 8:e82605. doi: 10.1371/journal.pone.0082605
Karl, D. M., and Tilbrook, B. D. (1994). Production and transport of methane in oceanic particulate organic matter. Nature 368, 732-734. doi: 10.1038/368732a0

Karstensen, J., Stramma, L., and Visbeck, M. (2008). Oxygen minimum zones in the eastern tropical Atlantic and Pacific oceans. Prog. Oceanogr. 77, 331-350. doi: $10.1126 /$ science. 1153847

Kemp, A. E. S., and Villareal, T. A. (2013). High diatom production and export in stratified waters - A potential negative feedback to global warming. Prog. Oceanogr. 119, 4-23. doi: 10.1016/j.pocean.2013.06.004

Kiørboe, T., Ploug, H., and Thygesen, U. H. (2001). Fluid motion and solute distribution around sinking aggregates. I. Small-scale fluxes and heterogeneity of nutrients in the pelagic environment. Mar. Ecol. Prog. Ser. 211, 1-13. doi: 10.3354/meps 211001

Kiørboe, T., Tiselius, P., Mitchell-Innes, B., Hansen, J. L. S., Visser, A. W., and Mari, X. (1998). Intensive aggregate formation with low vertical flux during an upwelling-induced diatom bloom. Limnol. Oceanogr. 43, 104-116. doi: 10.4319/lo.1998.43.1.0104

Klawonn, I., Bonaglia, S., Brüchert, V., and Ploug, H. (2015). Aerobic and anaerobic nitrogen transformation processes in $\mathrm{N}_{2}$-fixing cyanobacterial aggregates. ISME J. 9, 1456-1466. doi: 10.1038/ismej.2014.232

Knauer, G. A., Hebel, D., and Cipriano, F. (1982). Marine snow: major site of primary production in coastal waters. Nature 300, 630-631. doi: 10.1038/300630a0

Lam, P., Jensen, M. M., Kock, A., Lettmann, K. A., Pancherel, Y., Lavik, G., et al. (2011). Origin and fate of the secondary nitrite maximum in the Arabian Sea. Biogeosciences 8, 1565-1577. doi: 10.5194/bg-8-1565-2011

Lam, P., and Kuypers, M. M. M. (2011). Microbial nitrogen cycling processes in oxygen minimum zones. Annu. Rev. Mar. Sci. 3, 317-345. doi: 10.1146/annurev-marine-120709-142814

Lampitt, R. S., Hillier, W. R., and Challenor, P. G. (2001). Seasonal and diel variation in the open ocean concentration of marine snow aggregates. Nature 362, 737-739. doi: 10.1038/362737a0

Lehto, N., Glud, R. N., Nordi, G. A., Zhang, H., and Davison, W. (2014). Anoxic microniches in marine sediments induced by aggregate settlement: biogeochemical dynamics and implications. Biogeochemistry 119, 307-327.

Lomas, M. W., and Glibert, P. M. (2000). Comparisons of nitrate uptake, storage, and reduction in marine diatoms and flagellates. J. Phycol. 36, 903-913. doi: 10.1046/j.1529-8817.2000.99029.x

McIlvin, M. R., and Altabet, M. A. (2005). Chemical conversion of nitrate and nitrite to nitrous oxide for nitrogen and oxygen isotopic analysis in freshwater and seawater. Anal. Chem. 77, 5589-5595. doi: 10.1021/ac05 $0528 \mathrm{~s}$

Muller-Karger, F., Varela, R., Thunell, R., Scranton, M., Bohrer, R., Taylor, G., et al. (2001). Annual cycle of primary production in the Cariaco Basin: response to upwelling and implications for vertical export. J. Geophys. Res. 106, 4527-4542. doi: 10.1029/1999JC00029

Müller-Niklas, G., Schuster, S., Kaltenböck, E., and Herndl, G. J. (1994). Organic content and bacterial metabolism in amorphous aggregations of the Northern Adriatic Sea. Limnol. Oceanogr. 39, 58-68. doi: 10.4319/lo.1994.39. 1.0058

Nielsen, L. P. (1992). Denitrification in sediment determined from nitrogen isotope pairing. FEMS Microbiol. Ecol. 86, 357-362. doi: 10.1016/j.chemosphere.2013.07.063

Paerl, H. W., and Bebout, B. M. (1988). Direct measurement of $\mathrm{O}_{2}$-depleted microzones in marine Oscillatoria - relation to $\mathrm{N}_{2}$ fixation. Science 241, 442-445. doi: 10.1126/science.241.4864.442

Ploug, H. (2001). Small-scale oxygen fluxes and remineralization in sinking aggregates. Limnol. Oceanogr. 46, 1624-1631. doi: 10.4319/lo.2001.46.7.1624

Ploug, H., and Bergkvist, J. (2015). Oxygen diffusion limitation and ammonium production within sinking diatom aggregates under hypoxic and anoxic conditions. Mar. Chem. 176, 142-149. doi: 10.1016/j.marchem.2015.08.012

Ploug, H., Grossart, H. P., Azam, F., and Jørgensen, B. B. (1999). Photosynthesis, respiration, and carbon turnover in sinking marine snow from surface waters of Southern California Bight: implications for the carbon cycle in the ocean. Mar. Ecol. Prog. Ser. 179, 1-11. doi: 10.3354/meps179001

Ploug, H., Iversen, M. H., and Fischer, G. (2008). Ballast, sinking velocity, and apparent diffusivity within marine snow and zooplankton fecal pellets: implications for substrate turnover by attached bacteria. Limnol. Oceanogr. 53, 1878-1886. doi: 10.4319/lo.2008.53.5.1878 
Ploug, H., and Jørgensen, B. B. (1999). A net-jet flow system for mass transfer and microsensor studies of sinking aggregates. Mar. Ecol. Prog. Ser. 176, 279-290. doi: $10.3354 /$ meps 176279

Ploug, H., Kühl, M., Buchholz-Cleven, B. E. E., and Jørgensen, B. B. (1997). Anoxic aggregates - an ephemeral phenomenon in the pelagic environment? Aquat. Microb. Ecol. 13, 285-294. doi: 10.3354/ame013285

Revsbech, N. P. (1989). An oxygen microsensor with a guard cathode. Limnol. Oceanogr. 34, 474-478. doi: 10.4319/lo.1989.34.2. 0474

Schramm, A., Santegoeds, C. M., Nielsen, H. K., and others. (1999). On the occurrence of anoxic microniches, denitrification, and sulfate reduction in aerated activated sludge. Appl. Environ. Microbiol. 65, 4189-4196.

Shanks, A. L., and Reeder, M. L. (1993). Reducing microzones and sulfide production in marine snow. Mar. Ecol. Prog. Ser. 96, 43-47. doi: 10.3354/meps096043

Shanks, A. L., and Trent, J. D. (1979). Marine snow - microscale nutrient patches. Limnol. Oceanogr. 24, 850-854. doi: 10.4319/lo.1979.24.5.0850

Shanks, A. L., and Trent, J. D. (1980). Marine snow: sinking rates and potential role in vertical flux. Deep-Sea Res. Pt. A 27, 137-143. doi: 10.1016/01980149(80)90092-8

Simon, M., Grossart, H. P., Schweitzer, B., and Ploug, H. (2002). Microbial ecology of organic aggregates in aquatic ecosystems. Aquat. Microb. Ecol. 28, 175-211. doi: 10.1007/s00248-012-0147-2

Smetacek, V. S. (1985). Role of sinking in diatom life-history cycles ecological, evolutionary and geological significance. Mar. Biol. 84, 239-251. doi: 10.1007/BF00392493

Stocker, R., Seymour, J. R., Samadani, A., Hunt, D. E., and Polz, M. F. (2008). Rapid chemotactic response enables marine bacteria to exploit ephemeral microscale nutrient patches. Proc. Natl. Acad. Sci. U.S.A. 105, 4209-4214. doi: 10.1073/pnas.0709765105

Strauss, E. A., and Lamberti, G. A. (2000). Regulation of nitrification in aquatic sediments by organic carbon. Limnol. Oceanogr. 45, 1854-1859. doi: 10.4319/lo.2000.45.8.1854

Thiele, S., Fuchs, B. M., Amann, R., and Iversen, M. H. (2015). Colonization in the photic zone and subsequent changes during sinking determine bacterial community composition in marine snow. Appl. Environ. Microbiol. 81, 1463-1471. doi: 10.1128/AEM.02570-14
Thornton, D. C. O. (2002). Diatom aggregation in the sea: mechanisms and ecological implications. Eur. J. Phycol. 37, 149-161. doi: 10.1017/S0967026202003657

Tuomainen, J. M., Hietanen, S., Kuparinen, J., Martikainen, P. J., and Servomaa, K. (2003). Baltic Sea cyanobacterial bloom contains denitrification and nitrification genes, but has negligible denitrification activity. FEMS Microbiol. Ecol. 45, 83-96. doi: 10.1016/S0168-6496(03)00131-4

Turner, J. T. (2015). Zooplankton fecal pellets, marine snow, phytodetritus and the ocean's biological pump. Prog. Oceanogr. 130, 205-248. doi: 10.1016/j.pocean.2014.08.005

Villareal, T. A., Adornato, L., Wilson, C., and Schoenbaechler, C. A. (2011). Summer blooms of diatom-diazotroph assemblages and surface chlorophyll in the North Pacific gyre: a disconnect. J. Geophys. Res. 116:C03001.

Warembourg, F. R. (1993). "Nitrogen fixation in soil and plant systems," in Nitrogen Isotope Techniques, eds R. Knowles and T. H. Blackburn (New York, NY: Academic Press), 157-180.

Wright, J. J., Konwar, K. M., and Hallam, S. J. (2012). Microbial ecology of expanding oxygen minimum zones. Nat. Rev. Microbiol. 10, 381-394. doi: $10.1038 /$ nrmicro 2778

Yang, F., Troncy, E., Francoeur, M., Vinet, B., Vinay, P., Czaika, G., et al. (1997). Effects of reducing reagents and temperature on conversion of nitrite and nitrate to nitric oxide and detection of $\mathrm{NO}$ by chemiluminescence. Clin. Chem. 43, 657-662.

Ziervogel, K., and Forster, S. (2005). Aggregation and sinking behaviour of resuspended fluffy layer material. Cont. Shelf Res. 25, 1853-1863. doi: 10.1016/j.csr.2005.06.008

Conflict of Interest Statement: The authors declare that the research was conducted in the absence of any commercial or financial relationships that could be construed as a potential conflict of interest.

Copyright (C) 2016 Stief, Kamp, Thamdrup and Glud. This is an open-access article distributed under the terms of the Creative Commons Attribution License (CC BY). The use, distribution or reproduction in other forums is permitted, provided the original author(s) or licensor are credited and that the original publication in this journal is cited, in accordance with accepted academic practice. No use, distribution or reproduction is permitted which does not comply with these terms. 